\title{
AOR
}

Selected Papers of \#AoIR2019:

The $20^{\text {th }}$ Annual Conference of the Association of Internet Researchers Brisbane, Australia / 2-5 October 2019

\section{TRUSTED COMMONS: WHY 'OLD’ SOCIAL MEDIA MATTER}

\author{
Maxigas \\ Lancaster University \\ Guillaume Latzko-Toth \\ Laval University
}

\section{Context and argument}

The term social media is problematic. As Papacharissi puts it, "all media are social" and "invite [their] own form of sociality" (2015: 1). As a category, the term lacks a clear boundary. Further, using the phrase "social media" as a way to categorise a bound set of digital communication devices may be seen as a negation of the sociality fostered by other technological artifacts that existed prior to them. It pertains to the rhetoric of periodisation that has become commonplace in studies of digital media as the notion of newness has been instrumental in structuring the research agenda (Gitelman 2006; Park, Jankowski, and Jones 2011). Drawing attention to the most recent technologies contributes to framing already existing technologies as "old" in the derogatory sense of "obsolete" and "irrelevant". It obscures (and denies) the possibility for users of technologies that are not in the spotlight of the largest public's attention to contribute to a social critique of dominant technologies, overlooking their political and subversive potential.

By investigating all digital media in current use regardless of their "newness" nor the amplitude of their user base, we can see devices that enjoy continued use as legitimate technologies, rather than mere oddities surviving thanks to their users' nostalgic attachments to obsoleted machines - as reported in Lindsay (2003) on retrocomputing. Dunbar-Hester's work on low-power radio activism shows how political values attached to the understanding of media in continued use shape the appropriation of new technologies (2014). We would like to build on her arguments to show "how" contemporary use of "old" social media can inform a critique of new media. By "old" social media we mean pre-platform age digital communication protocols presenting what Hogan and Quan-Haase (2010: 310) call "social affordances"-notably many-to-

Suggested Citation: Maxigas, \& Latzko-Toth, G. (2019, October 2-5). Trusted commons: Why 'old' social media matter. Paper presented at AolR 2019: The $20^{\text {th }}$ Annual Conference of the Association of Internet Researchers. Brisbane, Australia: AolR. Retrieved from http://spir.aoir.org. 
many communication. An example of these is Internet Relay Chat, a long-standing protocol of real-time text conferencing.

While our relationship to technology is strongly structured around the modern myth of progress, it can be helpful to pay attention to users who go against the grain in their technological choices. In line with Edgerton's (2008) plea for decentering our historical accounts of technology from innovations to uses, we focus on the IRC case and argue that this decentralised, co-constructed (Latzko-Toth, 2014) communication infrastructure continues to serve social groups who tend to distrust proprietary platforms-groups who are key to the collaborative production of software, hardware and politics.

\section{Theoretical Framework}

Boltanski and Chiapello (2005) propose a theoretical framework where historical developments are analysed as an alternating series of critique and recuperation. Anne Barron already showed how FLOSS (Free and Open Source Software) social movement went through such an ideological cycle from critique (free software) to recuperation (open source software). Established as a critical response to the commodification of code that has been freely shared before by academics, amateurs, and corporations, in a few decades FLOSS technologies became an organic part of capital accumulation practices in the information technology industry (Barron 2013: 19).

Söderberg and Delfanti (2015) suggest that the critique/recuperation framework is general enough to be applied to the study of different time frames. Drawing on their conclusions, we suggest that the critique/recuperation framework of the pragmatic school can be applied to technological cycles over much narrower time frames (Maxigas 2017a). Indeed, it seems that user communities who managed to preserve control over their means of communication in the face of recuperative structural logics were ones that preferred the simplicity and flexibility of unfinished, co-constructed artifacts to the user friendly interfaces of platforms, or in other words, valuing the democratisation of expertise over the democratisation of technology (Maxigas 2017b).

\section{Methodology}

Our claim that IRC serves as preferred communication infrastructure of peer production communities-a trusted commons-rests on the study of three specific user groups from the realms of software, hardware and politics. In software, we looked at the communication practices of FLOSS developers. In hardware, we investigated the media use of hackerspace members, since these shared machine workshops are considered the infrastructure of peer production "in the physical realm" (Kostakis, 2014). In politics, we examined the reported technological choices of participants in the Anonymous hacktivist group, since they have been the most visible example of peer produced politics of the last years (Dagdelen, 2012).

We structured the data collection and systematic analysis into three phases:

a) The hypothesis was formulated based on our online and offline participative observation and historical ethnography. First author focused on the technical 
repertoire of hackers, while second author researched the social affordances of IRC networks. We noticed that the continued use of IRC constituted a routine practice in peer production communities while other user groups slowly but surely migrated away to more popular social media platforms over the years.

b) Then, we used quantitative, computational methods to test the hypothesis. We collected data from community platforms about how to contact the respective peer production projects for support. We analysed the frequency of IRC as a contact option offered by the projects, versus other means of communication. We verified the results by correlating them with the names of these projects occurring in the list of IRC channels on popular networks (mainly freenode.org).

c) Finally, we are completing a dozen semi-structured interviews with a diversity of users (casual and heavy users, server maintainers, developers) in order to contextualise and refine the results of the preliminary analysis. We use the findings from the quantitative phase as a prompt during the interviews.

\section{References}

Barron, Anne. 2013. Free Software Production as Critical Social Practice. Economy and Society, 42(4).

Boltanski, Luc, and Eve Chiapello. 2005. The New Spirit of Capitalism. New York: Verso.

Dagdelen, Demet. 2012. Anonymous, WikiLeaks and Operation Payback: A Path to Political Action through IRC and Twitter. Paper presented at the IPP2012 conference, Oxford Internet Institute, Oxford, UK.

Dunbar-Hester, Christina. 2014. Low Power to the People: Pirates, Protest, and Politics in Fm Radio Activism. Inside Technology. Cambridge: MIT Press.

Edgerton, David. 2008. The Shock of the Old: Technology and Global History Since 1900. London: Profile Books.

Gitelman, Lisa. 2006. Always Already New: Media History and the Data of Culture. Cambridge: MIT Press.

Hogan, Bernie, and Anabel Quan-Haase. 2010. Persistence and Change in Social Media. Bulletin of Science, Technology \& Society, 4: 309-315.

Kostakis, Vasilis. 2014. Production and Governance in Hackerspaces: A Manifestation of Commons-Based Peer Production in the Physical Realm? International Journal of Cultural Studies, 17(2).

Latzko-Toth, Guillaume. 2014. Users as co-designers of software-based media: The coconstruction of Internet Relay Chat. Canadian Journal of Communication, 39(4), 577595.

Lindsay, Christina. 2003. From the Shadows: Users as Designers, Producers, Marketers, Distributors, and Technical Support. In How Users Matter: The Co- 
Construction of Users and Technology, ed by. Nelly Oudshoorn and Trevor Pinch, 2950. Cambridge: MIT Press.

Maxigas. 2017a. Hackers Against Technology: Critique and Recuperation in Technological Cycles. Social Studies of Science, 47(6).

. 2017b. Keeping Technological Sovereignty: The Case of Internet Relay Chat. In Technological Sovereignty 2, ed by. Alex Haché. Vol. 2. Paris: Ritimo.

Papacharissi, Zizi. 2015. We Have Always Been Social. Social Media + Society, 1(1): 1-2.

Park, David W., Nicholas W. Jankowski, and Steve Jones, eds. 2011. The Long History of New Media: Technology, Historiography, and Contextualizing Newness. New York: Peter Lang.

Söderberg, Johan, and Alessandro Delfanti. 2015. Hacking Hacked! The Life Cycles of Digital Innovation. Science, Technology and Human Values, 40(5). 